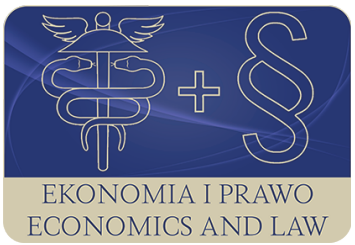

EKONOMIA I PRAWO. ECONOMICS AND LAW

Volume 18, Issue 1, March 2019

p-ISSN 1898-2255, e-ISSN 2392-1625

www.economicsandlaw.pl

ORIGINAL ARTICLE

received 24.07.2018; revised 01.10.2018; accepted 31.03.2019

Citation: Wiśniewski, M., \& Zieliński, J. (2019). Green bonds as an innovative sovereign financial instrument. Ekonomia i Prawo. Economics and Law, 18(1): 83-96. doi:10.12775/EiP.2019.007.

\title{
Green bonds as an innovative sovereign financial instrument
}

\author{
MARCIN WIŚNIEWSKI \\ corresponding author \\ Poznań University of Economics and Business, Faculty of Economics, Departament of Monetary \\ Policy and Financial Markets, al. Niepodległości 10, 61-875 Poznań, Poland \\ $\square$ marcin.wisniewski@ue.poznan.pl \\ (D) orcid.org/0000-0003-4609-6143
}

\section{JAKUB ZIELIŃSKI}

Poznań University of Economics and Business, Faculty of Economics, Departament of Monetary Policy and Financial Markets, Poland

曰jakub.zielinski@ue.poznan.pl

(D) orcid.org/0000-0002-5292-4438

\begin{abstract}
Motivation: There is a growing awareness of the impact that climate change is having on the world economy and the standards of living. Green bonds (GBs) are relatively new and innovative instruments on the financial market where the capitals are also invested in projects that generate environmental or climate benefits. The newness of this financial instrument could be the main reason behind the scarcity of scientific publications on green bonds; thus, it remains an undeveloped research area. One of the problems is also classifying securities as GBs. Therefore, it is exceedingly important to distinguish

labelled green bonds and unlabelled climate-aligned bonds.

Aim: In the article, the authors will present the evolution of the green bonds market and attempt to assess the observed and potential effects of green bonds' issuances, taking into account governments issues.

Results: Green bonds are the next stage of market growth. In the article, the authors will present the benefits of green bonds and the positive impact that their issuance has on the issuer and on investors' image as socially responsible entities. Therefore, strong investor demand can lead to oversubscription. Thus, green bonds could be one of the eas-
\end{abstract}


iest ways to attract investors and potentially increase issuance size which can contribute to lower costs of financing green public tasks.

Keywords: green bond; financial market; green growth; climate change; public debt JEL: G10; H63; O16; Q50

\section{Introduction}

As climate changes have a strong negative influence on human lives counteracting them has become the main target of contemporary development policies. Governments - from local to supranational level - have been trying to create sustainable development, one of the aims of which is to provide citizens with a healthy environment. What needs to be assured for the people is not only economic and social conditions, but also a clean natural environment. The public sector as well as private sectors should become engaged in development creation, as well as in raising funds for financing the progress. In this paper, the authors focus on the possibility of financing green activities by governments using a special kind of bonds - green bonds.

Firstly, we shall discuss the idea of sustainable development, concerning nature preservation actions, with a strong emphasis on financial resources that can be used in this process. Next, the authors will present the concept of bonds as the most popular debt instrument, with their classification. Then, the situation on the green bond market will be described. In the end, the authors will present the case of green bonds issued in 2016 by the Polish and French governments. On the basis of this example, the pros and cons of using the green bonds by the sovereigns will be discussed.

\section{Methods}

The main goal of this paper is to indicate the effects of green bonds issuance. In order to achieve this goal we will analyse the data presented by GBs' issuers and the reports of external institutions on GBs. The trends and regularities on the GB market, identified by the authors, will become the basis for stating the conclusions and guidelines for further GBs' issuances, especially in the execution of public tasks.

\section{Financing sustainable development}

The main reason for pursuing the environmental policy is the human need to live in a clean habitat, as it is a primary condition for maintaining citizens' health. The authorities should support such an economic development that would not be predatory for the environment in the long run.

In the last decades the approach of economic theorists and politicians has changed from totally focused on the outcomes of people's activities and func- 
tioning of the market to running a business which can provide the prevention of intra-generational equity and fair distribution of prosperity among contemporary living people (Jarno, 2017, pp. 17-22). This concept is nowadays known as sustainable development, which is an idea that combines three fields: environmental, economic and social. In the literature, we can find a great number of definitions of sustainable development, but one of the best known ones says that 'it is the creation of social and economic system that guarantees support for the following aims: increase in the real income, the improvement of the level of education, and the improvement in the populations' health and in the general quality of life' (Pearce et al., 1989, p. 13). We can also find another definition saying that 'it is a process of change in which the exploitation of resources, the direction of investments, the orientation of technological development, and institutional change are made consistent with future as well as present needs' (United Nation World Commission on Environment and Development, 1987).

Therefore, governments should perform certain actions and encourage entrepreneurs and households:

- to manage the natural resources in a sustainable way;

- to increase the consumption of renewable energy resources instead of the non-renewable ones;

- to ensure responsible waste management (recycling);

- to protect the environment, especially in urban areas;

- to ensure natural environment preservation.

The realization of these goals requires financial resources. Unfortunately, the income obtained by governments is limited and is not enough to fund all public tasks. The authorities have to decide which targets should be given priority and which ones can wait. The problem is that firstly the authorities need to address the provision of public goods, such as education, public safety, transport and all the other current needs. In the last decades, the activities of public and private sectors have been focused on providing the society with all the necessities while forgetting about natural environment. Of course, it is cheaper to pursue a policy without minding the nature, but such a policy has caused destruction of the environment, which is dangerous and threatening to human beings.

The approach of public and private sectors has changed lately, because it has become clear that without taking into account nature preservation, the economic and social development will not make sense. Nature deterioration - in order to obtain more money for economic growth - is acceptable in the short term, but in the long run it seems that environment reparations will be more expensive than the gains received so far.

Climate changes have pushed the governments and private entities to redefine their activities. The authorities started to promote activities aimed at environmental preservation and public tasks which can be regarded as environmental-friendly. Such a policy can support sustainable, responsible and long-term 
development. Similar tendencies can be found in the actions of the private sector - these days it is trendy to be socially responsible. Therefore, nowadays companies are trying hard to prove that their activities do not do harm to the nature; in fact, they want to show that their aim is to improve the natural environment. Investors, too, while constructing their portfolios, are willing to allocate their capital into those projects which can be perceived as socially or environmentally responsible.

As mentioned above, the resources of the public sector are limited, and their augmentation means a tax rise or debt enlargement. Thus, the realization of green activities - which are still secondary to the current tasks - is rather restrained. Generally, governments attempt to raise money by contracting debt from socially responsible investors - sometimes with philanthropic inclinations - investors who are interested not only in financial gains but also in environmental profits. This kind of debt often takes the form of bonds, which can be called green bonds. In this paper, the authors focus on green bonds as a method of pro-nature funds accumulation. Finally, the authors will try to determine whether green bonds are a significant, desirable and effective way to finance environmental projects.

\section{Green bonds in bonds classification}

Generally, a bond is a debt security that promises to make payments periodically for a specified period of time (Mishkin, 2004, pp. 3-4). Conventional bonds are typical debt instruments which mainly represent a liability of an issuer to pay interest in the future and to return a principal (par or nominal value) of the debt. Such a security is called a 'straight', 'plain vanilla' or 'bullet' bond, which signifies that there are no additional features attached to this liability (Choudhry, 2006, p. 3). This approach is common in finding debt capital for financing private and public activities, and these bonds account for the majority of the debt instruments traded in the world. Except those typical bonds, we can also distinguish some other sophisticated bonds - e.g. bonds which give the investor the rights assigned to the shareholders (Socha, 2003, pp. 120-125).

Many criteria can be used to classify bonds, e.g. the type of issuer, the aim of issuance, responsibility for the debt, payments construction. In this paper, bonds are classified according to two criteria - the type of issuer and the aim of financing - as presented in table 1 .

The first criterion divides bonds into private bonds and public bonds, which - depending on the level of authority — are divided into sovereign bonds (issued by the national government), communal bonds (issued by local communities or different types of local self-government), and sometimes supranational institution bonds (issued by, e.g. the European Investment Bank or the European Stabilization Mechanism).

Using the second criterion - the purpose of financing, we can distinguish between general bonds, which are used to obtain funds for all kinds of activities, 
and green bonds, which allow obtaining financial resources to finance pro-nature investments. Green bonds are a kind of 'theme' bonds, which are generally dedicated to a certain type of tasks to be financed. 'Theme' bonds were very often used in the past. For example, during wartime various countries used bonds, the so called war bonds, to finance their military needs. In the history we can also find bonds issued to raise money for huge infrastructural investments such as construction of railroads (railroad bonds) or highways (highway bonds). Lately, as a result of the observed climate changes, climate or green bonds have become a popular kind of securities, and it is this very type of bonds that is the subject of this paper.

\section{Green bonds as a new specific type of debt instrument}

Green bonds are becoming an increasingly established financial instrument used by a growing number of development banks, private companies or even municipal entities to raise capital for green investments that mitigate climate change. At first, each 'custom' financial instrument should be defined correctly so that it is possible to analyze it; hence, it is important to properly define green bond (GBs).

Green bonds are similar or even the same as regular bonds in the structure of the instrument. The main question is: 'how green' a project should be to be included in a green bond issue, and how stakeholders will go about measuring greenness (Wood \& Grace, 2011, p. 3). The International Capital Market Association (ICMA, 2016, p. 2) in Green Bond Principles, published in 2016, defined the green bond as a security differentiated from a regular bond by its label that the issuer undertakes to exclusively use the funds raised to finance or re-finance Green Projects, assets or business activities. All designated Green Project categories should provide clear environmental benefits which will be assessed and quantified by the issuer. Thus, in addition to evaluating standard financial characteristics (such as price, coupon, maturity and credit quality of the issuer), investors also assess the specific environmental allocation of the projects that the bonds will support.

ICMA is probably the main institution that classifies green bonds by having created Green Bonds White Paper called Green Bond Principles. It does not mean however, that no other entities can determine securities as GBs.

The table 2. refers to different standards of identification and certification of green bonds by miscellaneous institutions. Green bonds certification is exceptionally important for investors who aim to be 'socially responsible investors' (SRI).

Many institutions create their own standards for classifying bonds as GBs and evaluating them. Table 2 lists five different approaches to the classification of green bonds. When looking at the table 2. it becomes apparent that the basic element of any classification is the requirement of being a green investment. The most commonly used classifications are Green Bond Principles 
(GBPr) and CICERO 2nd Opinions. These two classifications differ only in their assessment of the level of the greenness of the project, which is not included in GBPr. It is interesting that CICERO (the Center for International Climate and Environmental Research) defined in detail what characteristics of projects make them 'green'. The Climate Bond Initiative and Green Bond Indices use the same criteria for identifying green bonds. The authors of these documents have extended their classification criteria with sector-specific eligibility compared to GBPr. The most extensive eligibility criteria for green bonds are set by Moody's Green Bond Assessments. In this document there are four elements which define the instrument as green bonds. An example of Moody's distinction is the use of ex-post monitoring. Moody's also uses quantitative weights in its identification. Such a method could be called point rating.

In order to classify bonds as GBs it would require overviewing all their issuances. That is why many bond issues have been labelled as, green' by the issuer who wants to inform potential investors about the influence of the funds raised to finance their environmentally friendly venture. The easiest way to highlight the pro-environmental nature of a bond is to indicate in the bond's name the green nature of the issue. This kind of bond should be called 'labelled green bonds'. There is also another kind of bond - unlabelled 'climate-aligned bond', the proceeds of which are not specially earmarked for environmental projects, but the underlying assets are climate-affected. It is not easy to distinguish either type of bonds. Hence, we ought to address the question of what the difference between green bonds and climate bonds is. The answer may not be very clear. Scientists from The University of Edinburgh defined green bonds as a financial instrument that supports environmental projects. Climate bonds ought to affect raising finance for investments in emission reduction or climate change adaptation. Thus, we cannot assume that every climate bond is a green bond, and not every green bond is related to climate ventures (Mackenzie et al., 2009, p. 15). For example, on the one hand, there are climate bonds used to build sea walls in cities threatened by the rising sea levels, which are not green instruments, and on the other hand, there are green bonds used to finance city parks which do not affect the climate in a direct way (Whiley, 2017).

The total global market for labelled green bonds and unlabelled climate-aligned bonds oscillates around USD 694 bn., where the share of unlabelled climate-aligned bonds is $83 \%$, and $17 \%$ for labelled green bonds (Climate Bond Initiative, 2016, pp. 2-4).

Chart 1 shows an inconsiderable share of green bonds in the structure of the global market for climate-aligned bonds. However, it should be mentioned that the green bond market is just a rising segment of the financial market so it is important to conduct a dynamic analysis of selected data. One of the factors is annual issuance, presented in chart 2 . An analysis of the annual issuance of green bonds shows a dynamic development of this segment of the financial market year by year. From 2007 to 2016, the volume of green bond issues in- 
creased by almost a hundred times. As expected, the issuance of green bonds will be still growing.

According to the OECD data, annual investment needs for renewable energy, energy efficiency and low-emission vehicles will increase from USD 839 bn. in 2015 to USD 4340 bn. in 2031-2035. This could be one of the reasons for the further development of the green bond market.

Standard\&Poor's 2014 data show that the average maturity of GBs is generally from 2 to 5 years (more than $40 \%$ ), and from 5 to 10 years (about 36\%). GBs with maturity of less than 2 years account for $14 \%$ of total GBs, and GBs with maturity of more than 10 years - close to $10 \%$. Moreover, most (up to even 90\%) GBs have AAA credit rating (Kochetygova \& Jauhari, 2014, p. 10). This derives from the fact that the biggest GBs issuers so far have been: the World Bank, the European Investment Bank, the Asian Development Bank, the African Development Bank, the Nordic Investment Bank, and the International Investment Corporation - entities with the highest creditability grades (Climate Brief, 2012, p. 3).

Looking at green bonds from the financial point of view it should be noted that they do not differ substantially from other bonds. As it was mentioned before, a green bond is a fixed-income financial instrument for raising capital from investors through the debt capital market. The issuer of GBs raises a fixed amount of capital from investors over a set period of time repaying the capital when the bond matures and paying an agreed amount of interest along the way. Hence, a few questions arise. Why should investors choose green bonds? Why should issuers decide to issue green bonds? Why are green bonds better than regular bonds? The main difference between green bonds and regular bonds is the purpose of bond issue allocation, but to answer the above questions it is necessary to point out some advantages and disadvantages of GBs, as shown in table 3.

The biggest advantage of green bond issue is the improved image of the investor (socially responsible investing) and issuer (Environment, Social and Governance). The remaining features relate to the characteristics of the regular bond, but there is a growing awareness of the impact that climate change is having on the world economy and standards of living. Thus, buying or issuing Green Bonds offers an opportunity to have climate friendly securities in investor or issuer portfolio. Hence, issuing green bonds is also one of the easiest ways to attract more potential investors than by any other way of financing.

\section{Green bonds as a possible way to finance investments by the public sector}

Demand in the Green Bond market has been driven largely by environmentally and socially responsible investors; that is why, over the years, various institutions have issued Green Bonds. The development of the Green Bond market is noticeable, but there was an undeveloped area - namely, the sovereign green 
bonds market. Local governments have been issuing green bonds since 2013 (The Commonwealth of Massachusetts issued their Green bonds in June 2013). Seemingly, the segment of municipal green bonds is relatively well developed, but by December 2016 no country had decided to issue green bonds (Green City Bonds Coalition, 2015, p. 9). The first state that issued green bonds was Poland. The issuance took place on 13 December 2016 (Moore, 2016). Through this Poland became a pioneer country that has issued a sovereign Green Bond.

Information from the Ministry of Development and Finance (2016) shows that demand at EUR 1.5bn (91 accounts) allowed to increase the issued amount to EUR $750 \mathrm{~m}$ from the initially expected EUR $500 \mathrm{~m}$. This means that the interest in buying sovereign green bonds by investors is colossal, which may have a positive impact on the development side of such securities. For the first sovereign issue the Green Bond Framework was created which included the allocation of proceeds, the rules of project evaluation and selection, the management of proceeds, the reporting rules and external review. According to the Green Bond Framework, the proceeds will be used to finance:

- clean transportation,

- renewable energy,

- sustainable agricultural operations,

- reclamation of heaps,

- National Parks,

- afforestation.

Considering the financial aspects of the first sovereign green bond issue, it should be noted that the profitability of this issue was comparable to the profitability of standard $5 \mathrm{Y}$ bonds in the euro market, and it was $0.634 \%$, while the annual coupon is $0.5 \%$. Poland's Green Bond can set a strong stimulus for sovereigns. Over the last few years, there has been a growing interest in green bonds as a way for the private sector to finance environmentally friendly purposes. Green bonds have generated attention from market participants, which also confirms how much the markets value green aspirations. Enormous demand caused by socially responsible investing and comparable costs could gradually lead to replacing standard treasury bonds with green bonds.

The second sovereign green bond issue in history was carried out by France. However, it does not mean that France did it only because it had also been done in Poland. Work on the issue of green bonds in both countries was conducted in parallel, but the Polish government took care of all the formalities in advance, so it was Poland that won the 'sovereign green bonds race'.

The French Treasury has issued green bonds primarily to finance the existing investments. Merely $7 \%$ of the bonds issuance proceeds will be used to finance new projects. However, it should be noted that the size of the French sovereign green bonds issue amounted to EUR 7 billion which is almost ten times more than in the case of Poland (Climate Action Programme, 2016). When comparing both issues, it is also important to analyze what proceeds will be financed. There 
are six eligible sectors, as outlined in the green bond framework for the French issue, including:

- buildings, e.g. investment in energy efficient buildings;

- transport, e.g. energy efficient transportation;

- energy, e.g. renewable energy and its integration into power systems;

- living resources and biodiversity, e.g. protection of natural areas;

- adaptation, e.g. observation systems;

- pollution control and eco-efficiency, e.g. the promotion of sustainable consumption.

A comparison of both the directions of the development lets us notice that there are different goals, but one common feature, which is the pro-environmental character of issue. Thus, the most important aspect of the issue of green bonds is using the proceeds to finance green projects (existing ones or new investments) regardless of the specific projects and irrespective of their name.

Except those two cases of sovereign green bonds, the next issuance is expected in Nigeria this year. The bonds have been provisionally earmarked for a range of climate-related initiatives including mass transit, land re-afforestation, remediation and solar projects (Climate Bond Initiative, 2017a). This evidence shows that GBs are a new trend in financial markets and public finance.

\section{Conclusions}

Green bonds are a relatively new instrument on the debt market. The newness of this financial instrument is probably the main reason behind the relatively weak green bond market. Thus, it is still an undeveloped but perspective research area. Over the past ten years the market of green bonds has grown both in terms of the amount of the issue and the number and type of issuers. Taking into account the growing awareness of the impact of climate protection and the growing number of environmentally-friendly investments, green bonds are one of the best ways to finance this kind of projects as the costs of their issue are generally not different from those of other bonds, while the green nature of the bond arouses investors' great interest.

The development of the green bonds market and the first sovereign issues of this kind of security can be called a sign of our times. The growing role of green investments, as a goal of sustainable development, shows that the economic and social evolution cannot be carried out without nature preservation. Green projects need green finance and this is a reason for labelling bonds and creating contemporary 'theme' bonds - the green bonds. The current issuances, conducted by Polish and French governments, show that there is a great demand for this type of securities. This instrument can be used to raise funds for sovereign projects at a relatively low cost. These two cases allow us to state that green bonds are the future of financial markets in supporting sustainable development in the world. 


\section{References}

Choudhry, M. (2006). An introduction to bond markets. Hoboken: Wiley \& Sons. Climate Action Programme. (2016). Record $\$ 7.5$ billion green bond issued by France. Retrieved 20.10.2017 from http://www.climateactionprogramme.org.

Climate Bond Initiative. (2016). Bonds and climate change: the state of market in 2016. Retrieved 20.10.2017 from https://www.climatebonds.net.

Climate Bond Initiative. (2017a). Climate bonds for beginners. Retrieved 20.10.2017 from https://www.climatebonds.net.

Climate Bond Initiative. (2017b). Green Bonds Market 2017. Retrieved 20.10.2017 from https://www.climatebonds.net.

Climate Brief. (2012). Financing the transition to a green economy: their word is their (green) bond? CDC Climate Research, 14.

Ehlers, T., \& Packer, F. (2017). Green bond finance and certification. BIS Quarterly Review, September.

Green City Bonds Coalition. (2015). How to issue a green muni bond. The green muni bonds playbook. Retrieved 20.10.2017 from https://www.climatebonds.net.

International Capital Market Association. (2016). Green bond principles. Retrieved 20.10.2017 from https://www.icmagroup.org.

Jarno, K. (2017). Carbon funds in climate policy. Warszawa: CeDeWu.

Kochetygova, J., \& Jauhari, A. (2014). Climate change, green bonds and index investing: the new frontier. Retrieved 20.10.2017 from https://us.spindices. com.

Mackenzie, C., Ascui, F., \& Hikish, D. (2009). Investor leadership on climate change. Retrieved 20.10.2017 from https://www.unglobalcompact.org.

Milken Institute. (2018). Growing the U.S. green bond market. Volume 2: actionable strategies and solutions. Retrieved 01.10.2018 from https://www.treasurer. ca.gov.

Ministry of Development and Finance. (2016). Green bond framework. Retrieved 20.10.2017 from https://www.finanse.mf.gov.pl.

Mishkin, F.S. (2004). The economics of money, banking and financial markets. New York: Pearson Addison Wesley.

Moore, E. (2016). Poland issues world's first green bonds. Retrieved 20.10.2017 from https://www.ft.com.

OECD \& Bloomberg Philanthropies. (2016). Green bonds. Mobilising the debt capital markets for a low-carbon transition: policy perspectives. Retrieved 20.10.2017 from http://www.oecd.org.

Pearce, D.W., Markandya, A., \& Barbier, E. (1989). Blueprint for a green economy. London: Routledge.

Socha, J. (2003). Rynek papierów wartościowych w Polsce. Warszawa: Olympus.

United Nation World Commission on Environment and Development. (1987). Our common future (Brundtland Report). Retrieved 20.10.2017 from http:// www.un-documents.net. 
Whiley, A. (2017). Lagos conference to set stage for Nigeria Sovereign Bond. Retrieved 20.10.2017 from https://www.climatebonds.net.

Wood, D., \& Grace, K. (2011). A brief note on the global green bond market. IRI Working Paper, February.

\section{Acknowledgements}

Author contributions: authors have given an approval to the final version of the article. Authors contributed to this work as follows: M.W. and J.Z. developed the concept and designed the study, J.Z. collected the data, M.W. and J.Z. analysed and interpreted the data, M.W. prepared draft of article, M.W. revised the article critically for important intellectual content.

Funding: this research was fully funded by authors own resources.

Note: the results of this study were presented in another form, such as abstract at 9th International Conference on Applied Economics Contemporary Issues in Economy (June 22-23, Torun, Poland). 


\section{Appendix}

Table 1.

Bonds classification

\begin{tabular}{lccc}
\hline \multirow{2}{*}{ Classification criteria } & \multicolumn{2}{c}{ Aim of financing } \\
\cline { 3 - 4 } & public sector & General goals & Green goals \\
\hline \multirow{2}{*}{ issuer } & private sector & regular public bonds & green public bonds \\
& regular private bonds & green private bonds \\
\hline
\end{tabular}

Source: Own preparation.

Table 2.

Characteristics of different Green Bond identification and certification

\begin{tabular}{|c|c|c|c|c|c|}
\hline Specification & $\begin{array}{l}\text { Green Bond } \\
\text { Principles }\end{array}$ & $\begin{array}{l}\text { Climate Bond } \\
\text { Initiative }\end{array}$ & $\begin{array}{l}\text { Green Bond } \\
\text { Indices }\end{array}$ & $\begin{array}{l}\text { CICERO 2nd } \\
\text { Opinions }\end{array}$ & $\begin{array}{c}\text { Moody's } \\
\text { Green Bond } \\
\text { Assessments }\end{array}$ \\
\hline $\begin{array}{l}\text { use of funds must be tied } \\
\text { to 'green' investment }\end{array}$ & $\mathrm{X}$ & $\mathrm{X}$ & $\mathrm{X}$ & $\mathrm{X}$ & $\mathrm{X}$ \\
\hline $\begin{array}{l}\text { sector-specific eligibility } \\
\text { criteria }\end{array}$ & & $\mathrm{X}$ & $\mathrm{X}$ & & \\
\hline $\begin{array}{l}\text { ex-post monitoring/ } \\
\text { assessment }\end{array}$ & & & & & $\mathrm{X}$ \\
\hline $\begin{array}{l}\text { granular assessments } \\
\text { of greenness }\end{array}$ & & & & $\mathrm{X}$ & $\mathrm{X}$ \\
\hline $\begin{array}{l}\text { quantitative weights for } \\
\text { different factors }\end{array}$ & & & & & $\mathrm{X}$ \\
\hline
\end{tabular}

Source: Own preparation based on Ehlers \& Packer (2017, p. 3).

Table 3.

Advantages and disadvantages of green bonds by issuers and investors

\begin{tabular}{|c|c|}
\hline \multicolumn{2}{|c|}{ For issuers } \\
\hline Advantages & Disadvantages \\
\hline $\begin{array}{l}\text { - demonstrating and implementing issuer's approach } \\
\text { to Environment, Social and Governance (ESG) issues }\end{array}$ & $\begin{array}{l}\text { - reputational risk if a bond's green credentials are } \\
\text { challenged }\end{array}$ \\
\hline $\begin{array}{l}\text { - improving diversification of bond issuer investor } \\
\text { base, potentially reducing exposure to bond demand } \\
\text { fluctuations }\end{array}$ & $\begin{array}{l}\text { - up front and ongoing transaction costs from labelling } \\
\text { and associated administrative, certification, report- } \\
\text { ing, verification and monitoring requirements (cost } \\
\text { estimates vary) }\end{array}$ \\
\hline $\begin{array}{l}\text { - strong investor demand can lead to oversubscriptions } \\
\text { and potentially increase issuance size }\end{array}$ & $\begin{array}{l}\text { - investors may seek penalties for a 'green default' } \\
\text { whereby a bond is paid in full but its issuer breaks }\end{array}$ \\
\hline $\begin{array}{l}\text { - evidence of more 'buy and hold' investors (lower } \\
\text { bond volatility in secondary market) }\end{array}$ & \\
\hline $\begin{array}{l}\text { - articulation and enhanced credibility of the sustain- } \\
\text { ability strategy }\end{array}$ & \\
\hline $\begin{array}{l}\text { - access to 'economies of scale' as majority of issuance } \\
\text { costs are in setting up the processes }\end{array}$ & \\
\hline
\end{tabular}




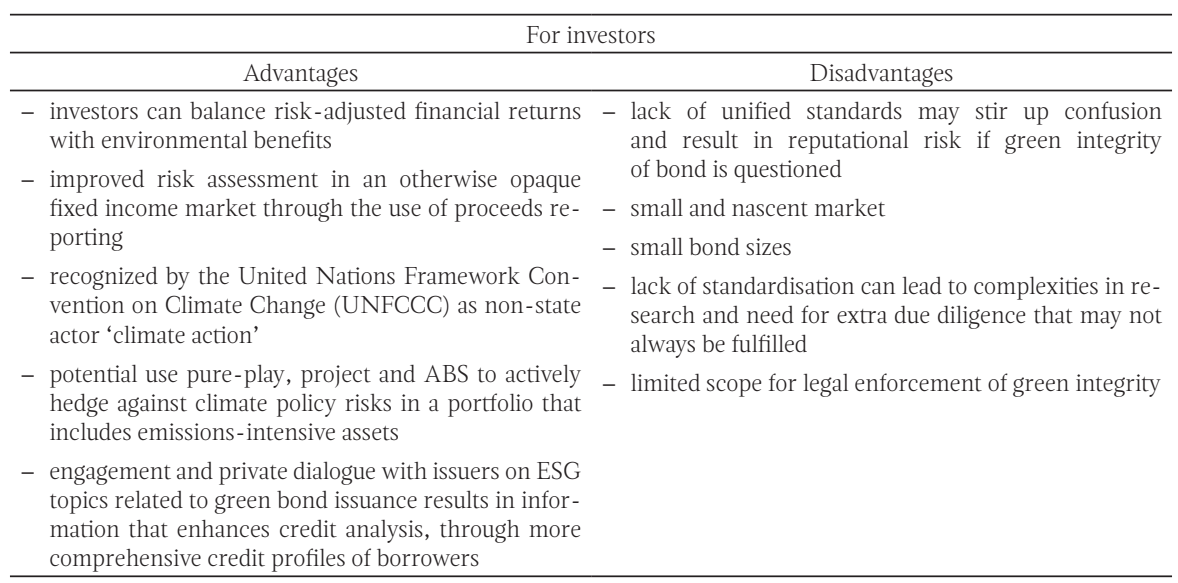

Source: OECD \& Bloomberg Philanthropies (2016).

\section{Chart 1.}

The structure of the global market for climate-aligned bonds covering both the labelled green bonds and unlabelled climate-aligned bonds in May 2016 (in billions USD and share in \%)

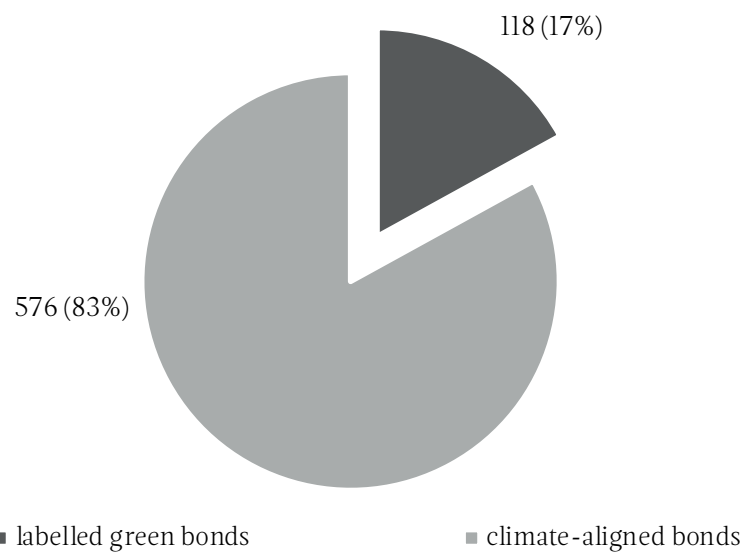

Source: Own preparation based on Climate Bond Initiative (2016, p. 3). 


\section{Chart 2.}

Global annual green bonds issuance in 2007-2017 (in billions USD)

160 150.0

140

120

100

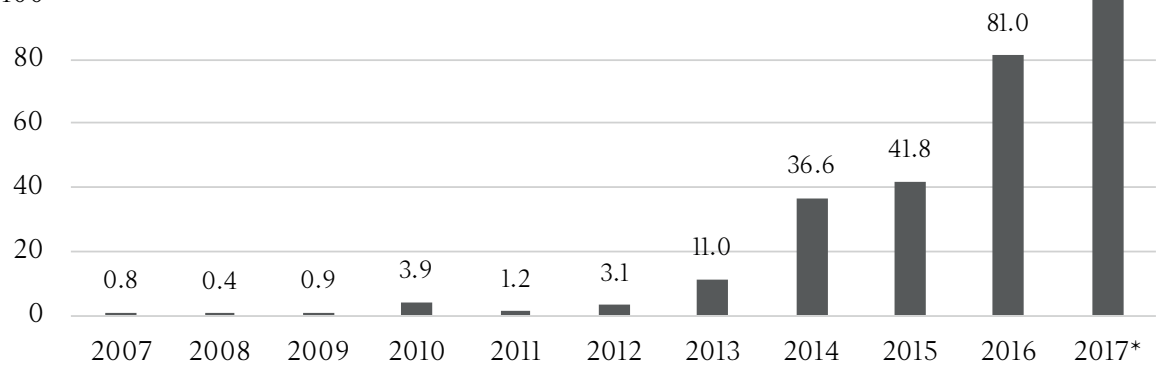

Note:

* denotes estimation.

Source: Own preparation based on Milken Institute (2018) and Climate Bond Initiative (2016, p. 1; 2017b). 